\title{
Estimating Enterprise Budgets of Selected Vegetable Grown by Small-scale Commercial and Subsistence Farms in the Eastern Cape Province of South Africa
}

\author{
Kibirige Douglas,ChiguwareTendai and Masika J Patrick \\ ${ }^{I}$ Department of Agricultural Economics and Management, Faculty of Agriculture University of Swaziland, \\ Luyengo, Swaziland.Email:kibirige@uniswa.sz \\ ${ }^{2}$ Research Associate at Agriculture and Rural Development Research Institute-University of Fort Hare, Eastern \\ Cape Province of South Africa \\ ${ }^{3}$ Professor at Fort Cox college of Agriculture and Forestry-Middledrift, P.O. Box 2187, King Williams Town \\ 5600, Eastern Cape Province of South Africa
}

\begin{abstract}
Rural Eastern Cape Province of South Africa is still rated high in terms of increasing and wide spread poverty despite the government support programmes like establishment small-scale irrigation schemes, input grants, and agricultural loans. Small-scale subsistence agricultural productivity is recorded low and anticipated to decline the more in this province. The low productivity and low gross margins accrued to subsistence farming has discouraged many rural farm householdsresulting in abandonment of their fields, and worsening the increasing rate of food insecurity, unemployment rate and high poverty levels in the Province. For survival, small-scale farmers have resorted to cultivating high value crops including vegetables, and these are thought to be an alternative source of incomes able to lift them out of the pathetic poverty. However, smallscale vegetable productivity is far less than the estimated potential yields, and information regarding their agroinput useand enterprise budget to inform their decisions seems to be scarce. Therefore this article was intended to estimate the enterprise budgets for selected vegetables among small-scale commercial, and subsistence farmers in Eastern Cape Province. Results generated in this article suggests that subsistence farmers use low amounts of agricultural inputs, and they are faced with low yields and gross margins despite their access to irrigation facilities. Based on these results, the authorsrecommend that public, private and NGOs should catalyse policies that target increased use of agro-inputs by small-scale farmers in rural Eastern Cape Province through agro-input subsidies, encourage decentralisation of agro-input distribution by private companies, improved access to agro-input credit services, and extension services geared towards optimal use of these inputs. Successful implementation of these policies may catalyse the transition from subsistence to commercialization of rural small-scale farming.
\end{abstract}

Keywords: Enterprise budgets, small-scale farmer, vegetables, gross margins, Eastern Cape Province of South Africa

\section{Introduction}

In rural South Africa, small-scale agriculture supplements the households' livelihoods. There are about four million smallholder farmers in South Africa, and $92 \%$ of these farmers are considered as subsistence farmers (Aliberet al.,2009).According to Statistic South Africa (2012), the 2011 census results revealed that $60 \%$ of the Eastern Cape Province's population derive their livelihood from smallholder subsistence farming. Among others, the commonly grown crops by subsistence small-scalefarmersinclude maize especially during summer, cabbage, potatoes, spinach, butternut, carrots grown mostly in winter, and rear livestock for household food security and income generation (Kibirige, 2013). Due to their high value, vegetable production has attracted both more large scale commercial and small-scale farmers to supplement government social grants and remittances (Kibirige, 2013). Small-scale farmers in the Eastern Cape Province depend on both rain-fed and irrigation farming, and mainly grow maize, potatoes and horticulture crops in small quantities just enough for home consumption (Liebenberg and Pardey, 2010).

In 2012, a comparative analysis of South African agricultural production performance was carried out by the Department of Agriculture, Forestry and Fisheries(DAFF) for period between 2009 and 2011 (DAFF, 2012).The comparison of the 2009/2010 and 2010/2011 results showed a slight increment in production volumes of horticulture products by $0.2 \%$. This was mainly attributed to increments in potato production by 6.8\% (134 834 tons), onion by 14.6\% (71 214 tons) and citrus fruits in particular grapefruit and lemons by 5.9\% (31 744 tons) (DAFF, 2012).However, it should be noted that about $98 \%$ of these estimated agricultural values are mainly attributed to commercial farmers with little smallholder production being considered in the national agricultural production and marketed output in South Africa (Kodua-Agyekum, 2009).Statistics generated by 
Statistics South Africa (2013) indicate an upward trend in vegetable production, although most data considered is collected from large commercial farms. Despite the increasing production of Vegetables in South Africa, local producers hardly meet the countries demand for the product. According to Theyse (2014), in 2013, vegetables worth 29 million US\$ were imported into South Africa from the African region. Figure 1 presents trends of selected vegetable production in South Africa.

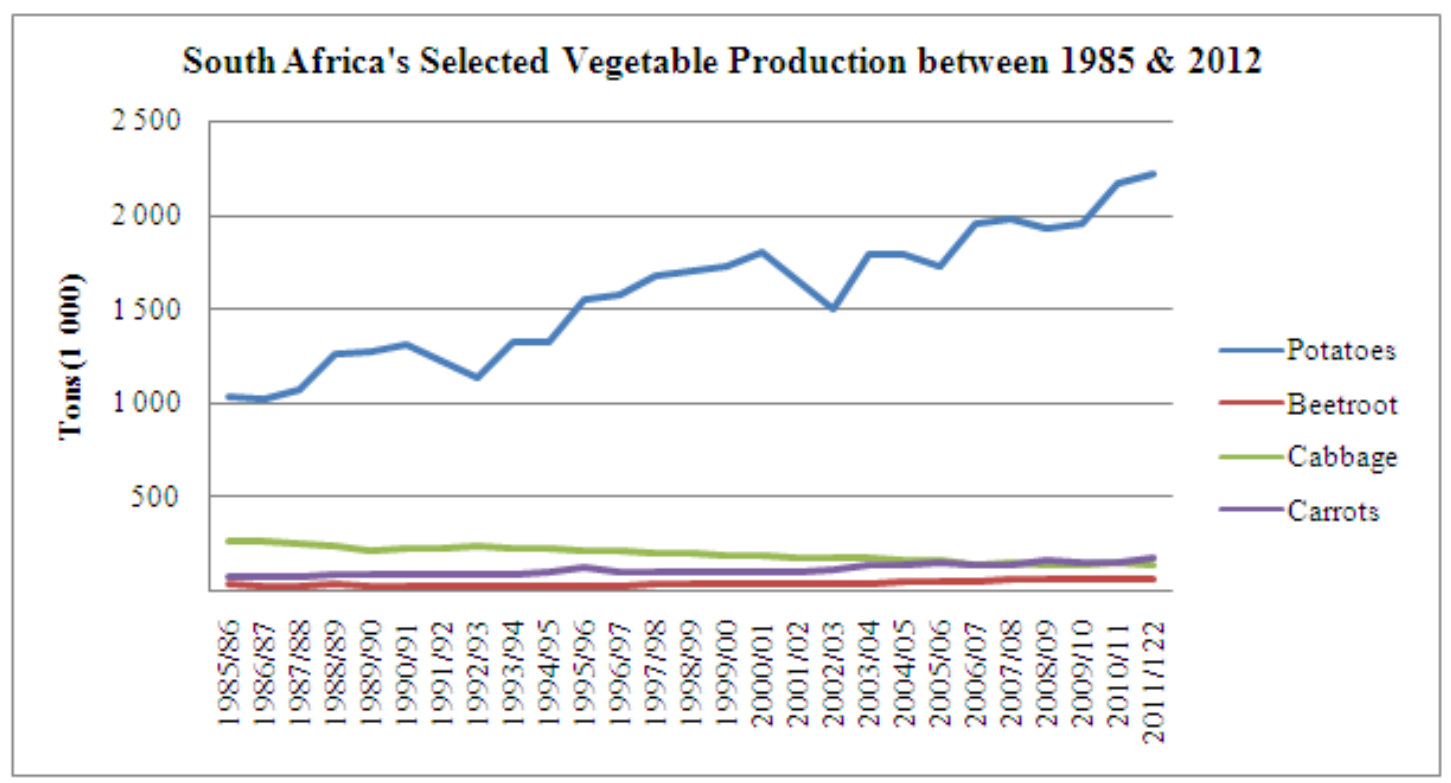

Figure 1: South Africa's selected Vegetable production trends between 1985 and 2012

Source: Statistics South Africa (2013)

The huge spending on vegetable importation in South Africa indicates a high demand for the products. Therefore, this calls for increased production of vegetables given the country's limited resources. According to Allemann and Young (2008), crop production systems are dependent on the botanical characteristics, environment, climate, and land size, location, inputs used, as well as other variables. Therefore, to attain optimal yields, natural resources, human capital, finances, and agro-inputs must be combined in the most efficient way (Kibirige, 2013). One sure way of investigating the proper use of agro-inputs gainfully includes establishment of the profitability of these crops. This helps to establish the viability and sustainability of an enterprise. The estimated profitability (gross margins) was based on one hectare for each selected enterprise presented in this study.

\section{Prerequisites for Establishing a Sustainable Farm Enterprise}

To establish a viable farm business project, essential production resources and requirements should be available. Land is one of these natural resources a prerequisite in farming. The conventional method is when planting crops and rearing animals is done on the open land, the common areas under production range from 0.25-2 hectares of land for communal subsistence farmers and 2 - 50ha for smallholder commercial ("emerging") farmers, but for a viable farm business project the area should be greater than one hectare (>1 ha).

In South Africa, of the $12.5 \mathrm{~km}^{3} /$ year total available fresh water, $31 \%$ is used for domestic purposes, $6 \%$ is used in industrial and 63\% is used in agricultural production (CIA, 2012; Kibirige, 2013). The 63\% agricultural water use signifies its importance in crop and livestock production. Both most crops and livestock can hardly survive in water scarce areas especially vegetables which require large quantities of water and they can only thrive under adequate soil moisture conditions (Kodua-Agyekum, 2009; Kibirige, 2013). For a sustainable farm business, there must be a reliable water supply source throughout the year includingrivers, lakes, springs, dams, borehole or any other available source. The quality of water especially in terms of $\mathrm{pH}$ has a great influence on the type of crops to be grown. While some crops prefer acidic conditions, others thrive on neutral to alkaline environments. For optimal crop production aimed at profit maximization, it is crucial to strike a balance between the water and soil conditions.

In the face of scarce rainwater and extreme weather conditions, efficient use of irrigation systems in countries like South Africa would be the best option. Irrigation can be defined as the deliberate application of water by humans to the soil for the purpose of supplying moisture essential for plant growth (Kodua-Agyekum, 2009). In areas like most parts of the Eastern Cape Province in South Africa where the water is not adequate, reservoirs including dams could be constructed and used as buffer for a sustainable farm production. In the 
Eastern Cape, different irrigation systems are being used by smallholder farmers to convey water in their gardens, and these include furrowing, sprinkler, hose pipe, bucket, and flooding and pivot irrigation systems (Kibirige, 2013). Use of sprinklers is the most common method of irrigation system employed by smallholder commercially oriented farmers and hose-pipe connected to water taps irrigation method is mainly practiced by communal subsistence farmers (Kodua-Agyekum, 2009; Kibirige, 2013).

A number of pumping units are used for drawing and pressurizing water into the system. The mostcommonly used are mono and centrifugal pumps. Considering the existence of adam or river, the cost of a complete setofnon-mechanized sprinklerirrigation and drip irrigation systemsper hectare are estimated at R26100and R27144, respectively, (The Encyclopaedia of Earth, 2008), as shown in Table 1. Applicants are strongly advised toconsult with irrigation officers for proper design of systemsbefore purchasing irrigation equipment. The annual costs incurred by thefarmer to pay for water, maintenance, and administration of the scheme, vary from R3132/ha to up to R13572/ha under exceptional circumstances. Location of the field, soil types,crops grown, the type of irrigation system and time ofyear in use dictates the amount of waterrequired per day.

Table 1: Estimated Costs for installation of the irrigation system in South Africa

\begin{tabular}{|l|l|l|}
\hline$\#$ & Type of the Irrigation system & Installation Costs (Rand/ha) \\
\hline 1 & Surface irrigation & $940-11484$ \\
\hline 2 & Non-mechanized sprinkler irrigation & $5220-26100$ \\
\hline 3 & Mechanized sprinkler irrigation & $7308-21924$ \\
\hline 4 & Micro irrigation and drip irrigation & $9396-27144$ \\
\hline
\end{tabular}

Source: The Encyclopaedia of Earth, 2008 (updated in May 2012)

Note: Considered inflation rate at $16 \%$ and foreign exchange rate at US $\$ 1 \approx \mathrm{R} 9$.

Availability of labour within the locality is crucial reason being farm production in most cases is labour intensive and thus requires adequate manpower for all operations (Kibirige, 2010). At least 4 permanent workers are required per hectare, and during peak periods especially in crop production activities like planting, weeding and harvesting the demand increases in use of casual workers (Kibirige, 2010). In livestock, preparation and storage of animal feed for winter may call for more casual labour.

Market availability is crucial for all successful business initiatives, and thus establishment of a market for the business prior to production is essential (Kohlsand Uhl, 2002; Dunns et al., 2006; Balunywa and Ntamu, 2012). Availability of market within the farm vicinity is crucial especially in reduction of transport costs of bulk produce. Therefore, soliciting or establishment of market for produce should be done at the onset of the business before drafting either a business or a cropping plan (Kohlsand Uhl, 2002). Market surety and inclusion in the business plan willguide all the farm operations, among others these include: types of enterprise; when to start planting crops/stock livestock; how much to grow/stock, and the resources needed for production (Dunns et al., 2006; Balunywa and Ntamu, 2012). The different market channels include fresh produce markets, supermarkets, wholesalers, retailer, hotels, institutions (schools, hospitals, and government offices), hawkers and individuals. For better prices and increased market accessibility, improved post-harvest handling techniques and value addition is important(Kohlsand Uhl, 2002; Dunns et al., 2006; Balunywa and Ntamu, 2012).

Financial capital is essential in farm business(KohlsandUhl, 2002). Appropriate forms of financial accessibility are extremely crucial in purchasing/acquisition of farm equipment and inputs for a more effective operation of a profitable farm business (Kibirige, 2013). Challenges faced by resource-poor smallholder farmers in regards to access to credit or financial support in most cases has been linked to low use of farm inputs leading to low farm yields (Kibirige, 2010). Therefore, this call for identification of potential fund sources in the initial stages of establishing a farm business. The different potential sources of funds include household incomes, government agricultural grants (can be in form of assets or subsidies), Non-Governmental Organisations (NGOs), and agricultural loans from banks and micro-finance institutions (Kibirige, 2013).

Ostrom (1998), FAO (2000), Padilla-Fernandez and Nuthall (2001), and Kibirige (2013) defined human capital as the acquired knowledge and skills through education, training and experience that an individual brings to an activity. Many studies including Padilla-Fernandez and Nuthall (2001), and Kibirige (2013) have attested the efficacy of basic farming skills and experience for improved farm production and productivity. Farm production is a very labour intensive and requires both dedication and skill to maximize output and profits (Kibirige, 2013). Therefore acquisition of farm knowledge through basic training in production and farm business principles or experience in the same field is very crucial. Acquisition of basic managerial skill is important and can enhance farmer's competitiveness in farm business. In instances where there is lacks of such skills and knowledge, both the owner of the farm and workers need to undertake trainings in farm production principles and farm business concepts to realize more output and profits (Ostrom, 1998, FAO, 2000; Kibirige, 2013). 
Generally, a farmer needs substantial knowledge about the different crop varieties and cultivars, and livestock breeds (FAO, 2000). Proper and efficient use of agro-inputs like the Integrated Pest Management (IPM) control system is important for sustainable farm production, reduce risks of agro-chemical hazards related to humansand animals, and reduced negative impacts to the general environment (Kibirige, 2013). Other farm management practices include record keeping and these records are important to facilitate proper monitoring of the enterprise and support decision making for the whole farm operations. Among essential records include, farm inventory of fixed assets, total farm land under production, total variable inputs bought, total variable inputs used, yields, and diseases and causes.

Other key factors important for a transformation from subsistence to small-scale commercial farming are fixed assets including: permanent water source (water reservoirs, dams and boreholes), irrigation equipment, fencing, store rooms, net shade, protective clothing, garden tools, permanent labour and other assets related to livestock production. These can be categorised into farm machinery, fencing material, buildings, protective clothes and garden tools, and infrastructure. When establishing a 1 ha of crop production or 3 ha of livestock production ideally there is no need of owning heavy machinery. In this situation hired machinery can be used in a few farm activities like land preparation. The common machinery important in farm production include: tractor, planter, and harrow.

The location of the project will dictate the type of fencing material. Most smallholder farmer and communal farmers are located in rural area where most livestock is reared on a free range system exposing crops to animal destruction. Therefore, fence with small animal proof material can be used to keep out small animals. The farmer may start with constructing less costly semi-permanent structures and after establishment the semi-permanent structures can be upgraded into permanent structures. These buildings may include netshade, store-room, packaging shed, and livestock shed/kraal/pen among others. Construction of these buildings should be guided by technical personnel for safety, hygiene, and prevention of pests and disease spread. In terms of infrastructure, farmers' access to services like electricity, roads, markets and telecommunication are crucial in facilitating value addition and marketing of agricultural produce. Availability and access to electricity facilitates water pumping, cooling facilities and other farm amenities including lighting and agro-processes is key for small-scale commercial farming.

The widely used/applied variable inputs in crop production are pesticides, seeds, herbicides, fertilizers, protective clothing, and the post-harvest handling related inputs like packaging materials. In livestock production, feeds (supplementary and pastures) vaccination, veterinary drugs, acaricides, dewormers.Other variable inputs are found under financial projection. Some of these variable inputs can be sourced from agroinput stores. Amounts of inputs purchased and applied in the field vary based on targeted output, the intensity of soil infertility, the level pest invasion and disease infection, and level of maturity and growth rate of crops and livestock.

Like any other business, establishing and operating a farm business calls for financial capital from owners' equity (Contribution) and/or credit/loans and grants from various financial institutions and government programs. Among others, sources of support may include government development programmes, NonGovernmental Organisations (NGOs), private business company's community support programmes, banks and other micro-finance institutions (Kibirige, 2013). For a sustainable farm business project, the principal amount (initial/start-up capital) covers the entire project establishment and operational costs for 1 hectare for crops and at least 3 ha for livestock production within a period not exceeding 12 months. The initial capital outlay can be up based on the prevailing input costs and anticipated profits per enterprise. In this case, the estimated enterprise budget assumesthat farmers have access to land as owner's contribution. The anticipated production levels and profits are based on key assumptions related to farm location, farm size, production costs, accessibility to loan and interest rates thereof, and input/output prices.

\section{Methodology}

Both primary and secondary data were used to estimate the profitability of enterprises under study. Primary data was collected from over 120 farmers in the Eastern Cape Province. A random sampling technique was used based on the available lists of farmers who were participating frequently in researches carried out by the Agricultural Rural Development and Research Institute (ARDRI)-housed by University of Fort Hare. According to Doll and Orazem (1984), and Tweeten (1979), profit can operationally be defined as the total revenue less total production costs and it is the basic economic measurement of profitability. In case of scarce information on fixed cost, profitability can be measured using and gross margin analysis. Gross margin is an appropriate measure to compare enterprises that place similar demands for limited resources like farmers and it is a good measure for short run and annual planning decisions (Castle et al., 1987). Furthermore, gross margin is a simple but a realistic measure of the performance of enterprises. According to Norman et al. (2002), gross margin refers to the gross income minus the variable costs associated with an enterprise/activity. 
Gross margins were evaluated by identifying and quantifying the Total Variable Costs (TVC) incurred by the farmers, and the Total Revenues (TR) realized in the production of selected enterprises per season. The TR is estimated as the prevailing market price of a given output (Py) multiplied by quantity of output sold $\left(\mathrm{Q}_{\mathrm{ys}}\right)$ $\left(\mathrm{P}_{\mathrm{y}} * \mathrm{Q}_{\mathrm{ys}}\right)$. Total variable costs is a summation of all input variable costs incurred by a given firm, and the input variable cost is estimated as the prevailing market price of a given input $\left(\mathrm{P}_{\mathrm{xi}}\right)$ multiplied by quantity of the input used $\left(\mathrm{Q}_{\mathrm{xi}}\right)\left(\mathrm{P}_{\mathrm{xi}} * \mathrm{Q}_{\mathrm{xi}}\right)$. Thus, TVC $=\sum_{\mathrm{i}=1}^{\mathrm{n}}\left(\mathrm{P}_{\mathrm{xi}} * \mathrm{Q}_{\mathrm{xi}}\right)$. Gross margin for each enterprise is calculated as:

$\mathrm{GM}=\left(\mathrm{P}_{\mathrm{y}} * \mathrm{Q}_{\mathrm{ys}}\right)-\sum_{\mathrm{i}=1}^{\mathrm{n}}\left(\mathrm{P}_{\mathrm{xi}} * \mathrm{Q}_{\mathrm{xi}}\right)$

\section{Enterprise Budget for One Hectare}

A brief and systematic description of each of the selected enterprise and its budget are presented in the following sections. The article focuses on comparison of small-scale commercial farming and subsistence farming of potatoes, spinach, butternut and carrots.

\section{Potato Enterprise}

\section{Results and Discussions}

Potatoes are root tubers that grow under optimum temperatures between $15^{\circ} \mathrm{C}$ and $18{ }^{\circ} \mathrm{C}$, and can survive between $7^{\circ} \mathrm{C}$ and $24^{\circ} \mathrm{C}$ of mean monthly temperatures. The crop is reported to be sensitive to frost (Allemann and Young, 2008). Potatoes thrive in sandy loam to loamy soils and are tolerant to soil acid with $\mathrm{pH}$ ranging from 4.3 to 6.1 . In potato production, high soil $\mathrm{pH}$ promotes scab disease. There are several potato cultivar including BP1, Up-to-Date, Vanderplank, Buffelspoort, Astrid, Hoëvelder and Mnandi (Allemann and Young, 2008). The recommended quantity of potato seedlings ranges from $3000 \mathrm{kgs}$ to $3600 \mathrm{kgs}$ per hectare, these potatoes take between 105 and 150 days to mature and the plant population per hectare of potatoes is approximately 130, 000 to 150,000 stems for table potatoes, and 160, 000 stems for seed potatoes. Table 2 displays the recommended seed rate, growth period and plant population of potatoes.

Table 2: Seed rate, Growth period and Plant population in Potato Production

\begin{tabular}{|l|l|l|}
\hline Seed rate & Growth period & population \\
\hline $\begin{array}{l}\text { Approximately } 100 \text { to } 120 \times 30 \mathrm{~kg} \\
\text { pockets/ha. }\end{array}$ & $\begin{array}{l}\text { The crop matures between } 105 \text { and } \\
150 \text { days }\end{array}$ & $\begin{array}{l}\text { Approximately } 130000 \text { to } 150000 \mathrm{stems} / \mathrm{ha} \text { for } \\
\text { table potatoes, and } 160000 \text { stems/ha for seed } \\
\text { potatoes. }\end{array}$ \\
\hline
\end{tabular}

Source: Allemann and Young(2008).

According to Kwazulu Natal Agriculture and Environmental Affairs (2006), Allemann and Young (2008), and Eastern Cape Department of Agriculture (2008), potato production is faced with many pests and diseases in South Africa. These pests and diseases include fruit fly, aphids,nematodes, tubermoth, millipedes,cutworm, wireworm,black maize beetle, and early blight, late blight, leaf roll, mosaic, common scab, bacterial wilt, soft rot, Fusarium, respectively. Among others, these pests and diseases can be controlled by pesticides and agro-chemical which include, Bulldock for worms, Confidor for aphids, Cartab for leaf miners, Counter for nematodes, Nemacure for nematodes, Tattoo for late blight, and Twist for early blight, respectively (see Table 3).

Table 3: Pests \& Diseases and their control in Potato Production

\begin{tabular}{|c|c|c|c|c|c|}
\hline Pests \& Disease & Control & Units & Quantity/ha & $\begin{array}{l}\text { Unit price } \\
\text { (Rand) }\end{array}$ & $\begin{array}{l}\text { Total cost } \\
\text { (Rand) }\end{array}$ \\
\hline \multirow{4}{*}{$\begin{array}{l}\text { Pests } \\
\text { Fruit fly, Aphids, } \\
\text { Nematodes, tuber moth, } \\
\text { millipedes, cutworm, wireworm, } \\
\text { black maize beetle } \\
\text { Diseases } \\
\text { Early blight, late blight, leaf roll, } \\
\text { mosaic, common scab, bacterial } \\
\text { wilt, soft rot, Fusarium wilt, dry } \\
\text { rot, black dot, silver scurf, black } \\
\text { scurf }\end{array}$} & Confidor (aphids) & Litre & 0.50 & 615 & 307.5 \\
\hline & Counter (nematodes) & $\mathrm{Kg}$ & 18.00 & 41 & 738 \\
\hline & Nemacure (nematodes) & Litre & 12.00 & 172 & 2064 \\
\hline & Tattoo (late blight) & Litre & 8.00 & 117 & 936 \\
\hline
\end{tabular}

Source: KZN Agriculture and Environmental Affairs (2006),Allemann and Young (2008) and Eastern Cape Department of Agriculture (2008). Note: unit prices inflated by $16 \%$ to estimate current (2013) prices.

Based on the recommended seed rate and other inputs, keeping other factors constant, Table 4 indicated that a commercially oriented farmer can harvest approximately $22000 \mathrm{kgs}$ of potatoes per hectare compared to only $2000 \mathrm{Kgs} /$ ha harvested by the subsistence farmer. Thus, commercially oriented small-scale farmers generate more revenues compared to the subsistence farmer in the Eastern Cape Province of South Africa. Results 
presented in the table further indicate that subsistence farmers plant far less seeds $(1.4 \mathrm{kgs} / \mathrm{ha})$ compared to commercial small-scale farmers who plant approximately $3600 \mathrm{~kg} / \mathrm{ha}$.

Table 4: Potatoes Enterprise Budget

\begin{tabular}{|c|c|c|c|c|c|c|}
\hline & \multicolumn{3}{|c|}{ Commercial Farming } & \multicolumn{3}{|c|}{ Subsistence Farming } \\
\hline & Quantity/ha & $\begin{array}{l}\text { Unit price } \\
\text { Rand }\end{array}$ & $\begin{array}{l}\text { Total } \\
\text { Rand }\end{array}$ & Quantity/ha & $\begin{array}{l}\text { Unit price } \\
\text { Rand }\end{array}$ & $\begin{array}{l}\text { Total } \\
\text { Rand }\end{array}$ \\
\hline \multicolumn{7}{|l|}{ Revenues (Gross Returns) } \\
\hline Production $(\mathrm{Kg})$ & 22000 & 2.50 & 55000 & 2000 & 5 & 10000 \\
\hline \multicolumn{7}{|l|}{ Variable Inputs Costs } \\
\hline Seeds $(\mathrm{Kg})$ & 3600 & 3.50 & 12600 & 1.4 & 130 & 182 \\
\hline Fertilizer $(\mathrm{Kg})$ 2:3:4 & 600 & 14.00 & 8400 & 125 & 14 & 1750 \\
\hline Fertilizer LAN & 500 & 12.00 & 6000 & & & \\
\hline Pesticide (Varieties) & & & 5970 & 2 & 60 & 120 \\
\hline \multicolumn{7}{|l|}{ labour (Man-days) } \\
\hline Land preparation/plough & Tractor (1d) & 650 & 650 & $30 \mathrm{md}$ & 30.00 & 900 \\
\hline Planting & Tractor (1d) & 590 & 590 & $14 \mathrm{md}$ & 30.00 & 420 \\
\hline Fertilizer Application & Tractor (1d) & 590 & 590 & $10 \mathrm{md}$ & 30.00 & 300 \\
\hline Weeding & $50 \mathrm{md}$ & 30 & 1500 & $50 \mathrm{md}$ & 30.00 & 1500 \\
\hline Spraying & Tractor (1d) & 400 & 400 & $14 \mathrm{md}$ & 30.00 & 420 \\
\hline Irrigation & $12 \mathrm{md}$ & 30 & 360 & & & \\
\hline Harvesting & $20 \mathrm{md}$ & 30 & 600 & $20 \mathrm{md}$ & 30.00 & 600 \\
\hline Transport costs & & & 1500 & & & 500 \\
\hline Marketing costs & & & 6200 & & & \\
\hline \multicolumn{3}{|c|}{ Total Variable Costs (TVC) } & 45360 & & & 6692 \\
\hline Net Gross Margin & & & 9640 & & & 3308 \\
\hline
\end{tabular}

$\mathrm{Kg}=$ Kilograms, $\mathrm{L}=$ Litre, $1 \mathrm{~d}=$ one working day, $\mathrm{md}=$ man-day $=8$ working hours days,

.Table 4 results further indicate that subsistence farmers apply less fertilizer $(125 \mathrm{~kg} / \mathrm{ha})$ and pesticides (spent only R120/ha) during potato production compared to the commercially oriented small-scale farmers who apply approximately 600kgs/ha of fertilizer and spent about R5970/ha. Use of small quantities of agro-inputs by subsistence small-scale farmer contributes greatly to their sub-optimal utilization of the natural resources (land and irrigation water), and hence leading to less gross margins per hectares earned. These results suggest that subsistence farmer have the potential of boosting their yield through increased use of the agro-inputs including seeds, fertilizer and pesticide.

\section{Spinach Enterprise}

According to Allemann and Young(2008), Spinach is a cool-season crop and grows well at temperatures between 7 and $24{ }^{\circ} \mathrm{C}$. The crop can withstand light frost. With well drained soils of about $500 \mathrm{~mm}$, the Spinach crop is highly adaptable. Among spinach varieties grown in South Africa include Fordhook Giantand Lucullus. Table 5 displays the recommended seed rate (approximately 7 to $9 \mathrm{~kg} / \mathrm{ha}$ ) for direct seeding, growth period ( about 2 to 3 months) and plant population ranging from 60000 to 80000 plants/ha)

Table 5: Seed rate, Growth period and Plant population in Spinach Production

\begin{tabular}{|c|c|c|}
\hline Seed rate & Growth period & Plant population \\
\hline $\begin{array}{l}\text { Approximately } 7 \text { to } 9 \mathrm{~kg} / \mathrm{ha} \text { for direct } \\
\text { seeding. }\end{array}$ & $\begin{array}{l}\text { Crop harvesting begins within } 2 \text { months } \\
\text { and continue to a maximum of } 3 \text { months }\end{array}$ & $\begin{array}{llllll}\begin{array}{l}\text { Approximately } \\
\text { plants/ha }\end{array} & 60 & 000 & \text { to } & 80 & 000 \\
\end{array}$ \\
\hline
\end{tabular}

Source: Allemann and Young(2008)

Spinach production is faced with risks of pests and diseases which include Nematodes, cutworm, American bollworm, loopers and aphids, and Cercospora leaf spot. These pest and diseases can controlled by application of pesticides and agro-chemical like Methomex,Bulldock,Confidor, Methamidifos, Folicure, andAquarite respectively. The recommended quantities of these agro-chemicals are displayed in Table 6.

Table 6: Pests and Diseases, and their Control in Spinach Production

\begin{tabular}{|l|l|l|l|l|l|}
\hline Pests \& Disease & Control & Units & Quantity/ha & $\begin{array}{l}\text { Unit price } \\
\text { (Rand) }\end{array}$ & $\begin{array}{l}\text { Total cost } \\
\text { (Rand) }\end{array}$ \\
\hline \multirow{2}{*}{$\begin{array}{l}\text { Pests } \\
\text { Nematodes, cutworm, American } \\
\text { bollworm, loopers and aphids }\end{array}$} & Methomex & $\mathrm{Kg}$ & 0.50 & 168.20 & 84.1 \\
\cline { 2 - 6 } $\begin{array}{l}\text { Diseases } \\
\text { Cercospora leaf spot }\end{array}$ & Bulldock & Litre & 0.15 & 266.80 & 40.02 \\
\cline { 2 - 6 } & Confidor & Litre & 0.50 & 614.80 & 307.4 \\
\cline { 2 - 6 } & Methamidifos & Litre & 0.80 & 75.40 & 60.32 \\
\cline { 2 - 6 } & Folicure & Litre & 1.00 & 174.00 & 174 \\
\cline { 2 - 6 } & Aquarite & Litre & 0.3 & 33.06 & 9.918 \\
\hline
\end{tabular}

Source: KZN Agriculture and Environmental Affairs (2006), Eastern Cape Department of Agriculture (2008). Note: unit prices inflated by $16 \%$ to estimate current (2013) prices. 
Results displayed in Table 7 indicate that subsistence farmers spinach productivity (1500 bundles/ha) is low compared to commercially oriented farming whose productivity is 7000 bundles/ha. The difference between the commercial farming and subsistence farming represents a big gap and poses opportunities for the later. Comparing the seed rate, commercial farmers plant far more seeds $(8 \mathrm{~kg} / \mathrm{ha}$ ) than subsistence farmers (only $1.4 \mathrm{~kg} / \mathrm{ha}$ ). Only $150 \mathrm{kgs} / \mathrm{ha}$ of fertilizers are applied in spinach production by subsistence farmers compared to larger amount of $500 \mathrm{~kg} / \mathrm{ha}$ applied by commercially oriented farmers.

Table 7: Spinach Enterprises Budget

\begin{tabular}{|c|c|c|c|c|c|c|}
\hline & \multicolumn{3}{|c|}{ Commercial Farming } & \multicolumn{3}{|c|}{ Subsistence Farming } \\
\hline & $\begin{array}{l}\text { Quantity/ } \\
\text { ha }\end{array}$ & $\begin{array}{l}\text { Unit } \\
\text { price } \\
\text { Rand } \\
\end{array}$ & $\begin{array}{l}\text { Total } \\
\text { Rand }\end{array}$ & Quantity/ha & $\begin{array}{l}\text { Unit } \\
\text { price } \\
\text { Rand } \\
\end{array}$ & $\begin{array}{l}\text { Total } \\
\text { Rand }\end{array}$ \\
\hline \multicolumn{7}{|l|}{ Revenues (Gross Returns) } \\
\hline Production (bundles) & 7000 & 5 & 35000 & 1500 & 5 & 7500 \\
\hline \multicolumn{7}{|l|}{ Variable Inputs Costs } \\
\hline Modified seeds $(\mathrm{Kg})$ & 8 & 130 & 1040 & 1.4 & 130 & 182 \\
\hline Fertilizer (Kg) 2:3:4 (30) & 500 & 14.00 & 7000 & 150 & 14 & 2100 \\
\hline Fertilizer $(\mathrm{LAN})(\mathrm{Kg})$ & 500 & 12.00 & 6000 & & & \\
\hline Pesticide (Various) & & & 676 & & & 160 \\
\hline Irrigation water $\left(\mathrm{mm}^{3}\right)$ & 500 & 4.0 & 2000 & & & \\
\hline \multicolumn{7}{|c|}{ labour (Man-days or Tractor) } \\
\hline Land preparation/plough & Tractor (1d) & 650 & 650 & $30 \mathrm{md}$ & 30.00 & 900 \\
\hline Planting & Tractor (1d) & 590 & 590 & $26 \mathrm{md}$ & 30.00 & 780 \\
\hline Fertilizer Application & Tractor $(1 \mathrm{~d})$ & 590 & 590 & $10 \mathrm{md}$ & 30.00 & 300 \\
\hline Weeding & $35 \mathrm{md}$ & 30 & 1050 & $35 \mathrm{md}$ & 30.00 & 1050 \\
\hline Spraying & Tractor (1d) & 400 & 400 & $14 \mathrm{md}$ & 30.00 & 420 \\
\hline Irrigation & $40 \mathrm{md}$ & 30 & 1200 & & & \\
\hline Harvesting & $30 \mathrm{md}$ & 30 & 900 & $30 \mathrm{md}$ & 30.00 & 900 \\
\hline Transport costs & & & 2500 & & & 500 \\
\hline Marketing costs & & & 8000 & & & \\
\hline \multicolumn{3}{|c|}{ Total Variable Costs (TVC) } & 29596 & & & 7292 \\
\hline Gross Margin & & & 5404 & & & 208 \\
\hline
\end{tabular}

$\mathrm{Kg}=$ Kilograms, $\mathrm{L}=$ Litre, $1 \mathrm{~d}=$ one working day, $\mathrm{md}=$ man-day = 8 working hours days,

The variable costs accrued to pesticides also suggest that commercial farmers apply far more pesticides than subsistence farmers where the later spends only about R160/ha and the former spend about R676/ha. Although commercial farmers' operational expenditures are higher than subsistence farmers', they generate more gross margins. An average commercially oriented farmer in Eastern Cape can generate gross margins worth approximately R5404/ha from spinach enterprise while an average subsistence farmer can only earn R208/ha gross margins from the same enterprise.

\section{Butternut Enterprise}

According to Allemann and Young (2008), butternut grows best in warm seasonal climate with optimum temperatures ranging between 18 and $30{ }^{\circ} \mathrm{C}$, and with monthly temperature at 10 to $32^{\circ} \mathrm{C}$. The crop poorly responds to frost and low temperatures. Soil characteristicsfor butternut production includes loamy soils with relatively high moisture content, deeper than $1000 \mathrm{~mm}$, and with an optimum $\mathrm{pH}$ ranging between 6.0 and 7.0. The butternut production seed rate is approximately 2 to $3 \mathrm{~kg} / \mathrm{ha}$ and crop matures in 90 to 100 days (see Table 8).

Table 8: Seed rate, Growth period in Butternut production

\begin{tabular}{|l|l|}
\hline Seed rate & Growth period \\
\hline Approximately 2 to $3 \mathrm{~kg} / \mathrm{ha}$. & $\begin{array}{l}\text { The crop matures between } \\
90 \text { and } 100 \text { days }\end{array}$ \\
\hline
\end{tabular}

Source: Allemann and Young(2008)

American bollworm, pumpkin fly, ladybird, aphids, RootknotNematodes, Red spider mite are some of the pests commonly known which attack butternut. Most common diseases faced by butternut in South Africa includePowdery and Downy mildews, leaf spot, fruit rot, mosaic, Fusarium wilt, Anthracnose, among others. Remedy for infested butternut crops, include application of pesticides and agro-inputs like Gallant Super, Confidor, Methamidifos,Dipterex,Trimangol,Oscar, andAquarite for pests, respectively. Voema flowerand fruit was identified for disease control. Table 9 shows the pests and diseases, how they are controlled, recommended quantities of the pesticides and estimated costs in South African Rand. 
Table 9: Pests \& Diseases and their control in Potato Production

\begin{tabular}{|c|c|c|c|c|c|}
\hline Pests \& Disease & Control & Units & Quantity/ha & $\begin{array}{l}\text { Unit price } \\
\text { (Rand) }\end{array}$ & $\begin{array}{l}\text { Total cost } \\
\text { (Rand) }\end{array}$ \\
\hline \multirow{8}{*}{$\begin{array}{l}\text { Pests } \\
\text { American bollworm, pumpkin } \\
\text { fly, ladybird, aphids, Rootknot } \\
\text { nematodes, Red spider mite, } \\
\text { Diseases } \\
\text { Powderyand Downy } \\
\text { mildews, leaf spot, fruit rot, } \\
\text { mosaic, Fusarium wilt, } \\
\text { Anthracnose, }\end{array}$} & Gallant Super & Litre & 0.85 & 266.8 & 226.78 \\
\hline & Confidor & Litre & 0.50 & 614.8 & 307.4 \\
\hline & Methamidifos & Litre & 3.20 & 75.4 & 241.28 \\
\hline & Dipterex & $\mathrm{Kg}$ & 0.40 & 243.6 & 97.44 \\
\hline & Trimangol & Litre & 12.00 & 40.6 & 487.2 \\
\hline & Oscar & Litre & 0.60 & 174 & 104.4 \\
\hline & Aquarite & Litre & 5.10 & 33.64 & 171.564 \\
\hline & Voemaflowerand fruit & Litre & 6.00 & 51.04 & 306.24 \\
\hline
\end{tabular}

Source: KZN Agriculture and Environmental Affairs (2006), and Allemann and Young (2008), Eastern Cape Department of Agriculture (2008). Note: unit prices inflated by 16\% to estimate current (2013) prices.

Commercial farmers are more likely to have a higher productivity than subsistence farmers. Results presented in Table 10 suggest that commercial farmers on average can produce approximately $25000 \mathrm{~kg} / \mathrm{kg}$ of butternut and subsistence can produce only $4000 \mathrm{~kg} / \mathrm{ha}$ of the same crop. The low yields suffered by subsistence farmers may be as a result of low agro-input application as results of this article further reveal that they only use $3 \mathrm{kgs} / \mathrm{ha}$ of recycled local seeds, apply $150 \mathrm{kgs} / \mathrm{ha}$ of fertilizer and spend only R120/ha on purchase of pesticides compared to commercial farmers who plant $2.5 \mathrm{kgs} / \mathrm{ha}$ of improved high yielding seeds, $500 \mathrm{kgs} / \mathrm{ha}$ of fertilizer and purchase pesticides worth 2000 South African Rand.

Table 10: Butternut Enterprise Budget

\begin{tabular}{|c|c|c|c|c|c|c|}
\hline & \multicolumn{3}{|c|}{ Commercial Farming } & \multicolumn{3}{|c|}{ Subsistence Farming } \\
\hline & Quantity/ha & $\begin{array}{l}\text { Unit price } \\
\text { Rand }\end{array}$ & $\begin{array}{l}\text { Total } \\
\text { Rand }\end{array}$ & Quantity/ha & $\begin{array}{l}\text { Unit price } \\
\text { Rand }\end{array}$ & $\begin{array}{l}\text { Total } \\
\text { Rand }\end{array}$ \\
\hline \multicolumn{7}{|l|}{ Revenues (Sales) } \\
\hline Production $(\mathrm{Kg})$ & 25000 & 3 & 75000 & 4000 & 4 & 16000 \\
\hline \multicolumn{7}{|l|}{ Variable Inputs Costs } \\
\hline Modified seeds $(\mathrm{Kg})$ & 2.5 & 130 & 325 & & & \\
\hline Recycled/local seed Kg & & & & 3 & 50 & 150 \\
\hline Fertilizer $(\mathrm{Kg}) 2: 3: 4$ & 500 & 14.00 & 7000 & 150 & 14 & 2100 \\
\hline Fertilizer LAN $(\mathrm{Kg})$ & 200 & 12.00 & 2400 & & & \\
\hline Pesticide (various) & & & 2000 & 2 & 60 & 120 \\
\hline Irrigation water pump & & & 300 & & & \\
\hline \multicolumn{7}{|l|}{ labour (Man-days) } \\
\hline Land preparation/plough & Tractor $(1 \mathrm{~d})$ & 650 & 650 & $40 \mathrm{md}$ & 30.00 & 1200 \\
\hline Planting & Tractor (1d) & 590 & 590 & $20 \mathrm{md}$ & 30.00 & 600 \\
\hline Fertilizer Application & Tractor (1d) & 590 & 590 & $14 \mathrm{md}$ & 30.00 & 420 \\
\hline Weeding & $50 \mathrm{md}$ & 30 & 1500 & $50 \mathrm{md}$ & 30.00 & 1500 \\
\hline Spraying & Tractor (1d) & 400 & 400 & $14 \mathrm{md}$ & 30.00 & 420 \\
\hline Irrigation & $10 \mathrm{md}$ & 30 & 300 & & & \\
\hline \multicolumn{7}{|l|}{ Post-harvest costs } \\
\hline Harvesting & $14 \mathrm{md}$ & 30 & 420 & $14 \mathrm{md}$ & 30.00 & 420 \\
\hline Transport costs & & & 1500 & & & 500 \\
\hline Market costs & & & 7214 & & & \\
\hline \multicolumn{3}{|c|}{ Total Variable Costs (TVC) } & 25189 & & & 7430 \\
\hline Net gross Margin & & & 49811 & & & 8570 \\
\hline
\end{tabular}

$\mathrm{Kg}=$ Kilograms, $\mathrm{L}=$ Litre, $1 \mathrm{~d}=$ one working day, $\mathrm{md}=$ man-day $=8$ working hours days,

The difference in Total Variable Costs (TVC) reflects how much and efficient use of agro-inputs by subsistence and commercial farming. Subsistence farmers can only spend approximately R7430/ha in purchase and use of agro-inputs compared to about R25189/ha spent by commercial farmers. Use of more inputs efficiently can be explained by the higher gross margins earned by commercially oriented farmers (approximately R49811/ha) than subsistence farmers (approximately R8570/ha).

\section{Carrot Enterprise}

Allemann and Young(2008) describe the production of carrots as follows: They are regarded as coolseason crop, with 15 to $18{ }^{\circ} \mathrm{C}$ optimum growth temperature and tolerate moderate frost. The crop can survive under high temperatures of $30^{\circ} \mathrm{C}$ and higher. The monthly mean temperature for optimal growth ranges between 7 and $24{ }^{\circ} \mathrm{C}$. The desired soil characteristics for optimal production include deep (400mm to 600mm), loose, well-drained, sandy to loamy soils with pH 5.0 to 6.0. Carrot cultivars include Cape Market, Fancy, Ideal Red, and Kuroda, among others. Carrot production seed rate is 2 to $4 \mathrm{~kg} / \mathrm{ha}$, with a growth period of about 90 to 
120days, and approximate plant population of 80 to 150 plants/metres squared. This information is shown in Table 11.

Table 11: Seed rate, Growth rate and Plant population in Carrot production

\begin{tabular}{|l|l|l|}
\hline Seed rate & Growth period & Plant Population \\
\hline 2 to $4 \mathrm{~kg} / \mathrm{ha}$ & Approximately 90 to 120 days & Approximately 80 to 150 plants/m2 \\
\hline
\end{tabular}

Source: Allemann and Young(2008)

Carrots attract pests and diseases like Nematodes, American bollworm, plusialooper, aphids, cutworm, wireworm, and Leaf spot, soft rot and Sclerotinia rot, respectively. Some of the agro-chemicals or pesticides that can be used to reduce on the infestation include Nemacur,Dimenton-smethylAluminium phosphate, and Mancozeb/Dithane M45. Table 12 presents the common pests and diseases and agro-chemicals important in controlling these pests and diseases.

Table 12: Pests and Diseases, and their control in carrots Production

\begin{tabular}{|c|c|}
\hline Pests \& Disease & Control \\
\hline \multirow{4}{*}{$\begin{array}{l}\text { Pests } \\
\text { Nematodes, American bollworm, plusialooper, } \\
\text { aphids, cutworm, wireworm } \\
\text { Diseases } \\
\text { Leaf spot, soft rot, Sclerotinia rot }\end{array}$} & Nemacur \\
\hline & Dimenton-smethyl \\
\hline & $\begin{array}{l}\text { Aluminium } \\
\text { phosphate }\end{array}$ \\
\hline & $\begin{array}{l}\text { Mancozeb/ } \\
\text { Dithane M45 }\end{array}$ \\
\hline
\end{tabular}

Source: Allemann and Young (2008).

The carrot enterprise budget suggest that subsistence farming is less productive compared to commercial farming where the former produces far less carrots $(12000 \mathrm{~kg} / \mathrm{ha})$ compared to $30000 \mathrm{~kg} / \mathrm{ha}$ produced by the later. Furthermore, subsistence farmers use fewer inputs in carrot production compared to commercial farmers as results shown in Table 13 indicate that the former use only about $1.4 \mathrm{~kg} / \mathrm{ha}$ of seeds, $150 \mathrm{~kg} / \mathrm{ha}$ of fertilizer, and they spend about R120 on pesticide purchases while the later plant about $4 \mathrm{~kg} / \mathrm{ha}$ of seeds, apply approximately $500 \mathrm{~kg} / \mathrm{ha}$ of fertilizer and averagely spend R1500/ha on pesticide purchases.

Table 13 Carrot Enterprise Budget

\begin{tabular}{|c|c|c|c|c|c|c|}
\hline & \multicolumn{3}{|c|}{ Commercial Farming } & \multicolumn{3}{|c|}{ Communal Farming } \\
\hline & Quantity/ha & $\begin{array}{l}\text { Unit price } \\
\text { Rand }\end{array}$ & $\begin{array}{l}\text { Total } \\
\text { Rand }\end{array}$ & Quantity/ha & $\begin{array}{l}\text { Unit price } \\
\text { Rand }\end{array}$ & $\begin{array}{l}\text { Total } \\
\text { Rand }\end{array}$ \\
\hline \multicolumn{7}{|l|}{ Revenues (Sales) } \\
\hline Production $(\mathrm{Kg})$ & 30000 & 3 & 90000 & 12000 & 3 & 36000 \\
\hline \multicolumn{7}{|l|}{ Variable Inputs Costs } \\
\hline Modified seeds $(\mathrm{Kg})$ & 4 & 130 & 520 & 1.4 & 130 & 182 \\
\hline Fertilizer (Kg or L) $2: 3: 4$ & 500 & 14.00 & 7000 & 150 & 14 & 2100 \\
\hline Fertilizer LAN & 150 & 12.00 & 1800 & & & \\
\hline Pesticide (Litres or Kg) & & & 1500 & & & 120 \\
\hline Irrigation water pump & & & 300 & & & \\
\hline \multicolumn{7}{|l|}{ labour (Man-days) } \\
\hline Land preparation/plough & Tractor (1d) & 650 & 650 & $38 \mathrm{md}$ & 30.00 & 1140 \\
\hline Planting & Tractor (1d) & 590 & 590 & $26 \mathrm{md}$ & 30.00 & 780 \\
\hline Fertilizer application & Tractor (1d) & 590 & 590 & $10 \mathrm{md}$ & 30.00 & 300 \\
\hline Weeding & $47 \mathrm{md}$ & 30 & 1410 & $47 \mathrm{md}$ & 30.00 & 1410 \\
\hline Spraying & Tractor (1d) & 400 & 400 & $14 \mathrm{md}$ & 30.00 & 420 \\
\hline Irrigation & $10 \mathrm{md}$ & 30 & 300 & & & \\
\hline Harvesting & $30 \mathrm{md}$ & 30 & 900 & $20 \mathrm{md}$ & 30.00 & 600 \\
\hline Transport costs & & & 1000 & & & 300 \\
\hline Marketing costs & & & 8000 & & & \\
\hline \multicolumn{3}{|c|}{ Total Variable Costs (TVC) } & 24960 & & & 7352 \\
\hline Net gross Margin & & & 65040 & & & 28648 \\
\hline
\end{tabular}

$\mathrm{Kg}=$ Kilograms, $\mathrm{L}=$ Litre, $1 \mathrm{~d}=$ one working day, $\mathrm{md}=$ man-day $=8$ working hours days,

Amount of direct total variable costs may reflect the amount of agro-input and machinery used in crop production.As expected, commercially oriented farmers are more likely to invest more in operational costs compared to the subsistence farmers. According to results shown in Table 13, commercial farmers spend about R24960 as total variable Costs while subsistence farmers spend only R7352 as their total variable costs. Results further indicate that subsistence farmers are more likely to generate far less profit in carrot production compared to commercially oriented farmers. Subsistence can generate only about R28648 compared to the commercially oriented farmers who are more likely to generate at least about R65040 on average. 


\section{Conclusions and Recommendations}

Rural subsistence farmers in the Eastern Cape province of South African use natural resources including land and irrigation water sub-optimally and less profitably. This is reflected in the far less agro-inputs and mechanization used by subsistence farmers in production of vegetables compared to the commercially oriented farmers. The low use of agro-inputs by rural subsistence farmers may be attributed to poor distribution channels of agro-inputs in rural communities, lack of funds to purchase or lack of knowledge about the optimal application of the inputs, among others. Low use of inputs limits farmers to realize higher yields and gross margins in vegetable production as reflected. Low productivity and gross margins earned by subsistence farmers as compared to the commercially oriented small-scale farmers suggest that the subsistence farmers have room to expand their productivity and profitability. This can be of great importance in reducing on rural household dependence on government social grants, income inequalities, improving food insecurity, and uplifting rural households from abject poverty.

This article recommends that government, Non-Governmental Organisations (NGOs), Community Based Organisations (CBOs) and the private sector should ensure increased farmers' access to agro-inputs and affordability through drafting and catalysing policy related to agro-input regulations in the country, access toagro-input subsidies, access to agro-input financial services, attracting decentralised agro-input distribution in rural areas, and extension services targeted towards trainings on optimal useagro-inputs. In addition, establishment and strengthening farmers' associations should be encouraged by stakeholders as an alternative way of pulling resources (agro-chemicals, farm labour, and farm tools) together, lobbing for input-credit from financial institution, and attracting contractual farming.Farmers' associations also ease the tasks of trainers and extension workers as they reduce on stress of mobilization, and transport and communication costs. It should be noted that initiation, implementation and evaluation (throughout the project cycle) ofespecially rural development policies and programmes need to be participatory involving all stakeholders.

\section{Acknowledgement}

We acknowledge the support provided by the Department of Agriculture, Forestry and Fisheries (DAFF)-South Africa through Agricultural Rural Development Research Institute (ARDRI)-university of Fort Hare, South Africa. Thanks also to Mr. Lawrence Musisi who helped us with some information important in writing this article.

\section{References}

[1]. Aliberetet al.(2009), Strategies to support South African smallholders as a contribution to government's second economy strategy: Situation analysis, Research report 41, Volume 1: fieldwork findings and main conclusions, Published by the Institute for Poverty, Land and Agrarian Studies, School of Government, Faculty of Economic and Management Sciences, University of the Western Cape, South Africa.

[2]. Allemann L. and YoungB.W. (2008), Vegetable production in a nutshell: Directorate Agriculture Information Service, Department of Agriculture in cooperation with KwaZulu-Natal Department of Agriculture and Environmental Affairs: Printed and published by Department of Agriculture, Pretoria, South Africa.

[3]. BalunywaW.,and Ntamu D. N.(2012): "Social Marginalization of Women, Business Start-up and Poverty Alleviation: A Case of Women Entrepreneurs in Roadside Markets in Uganda": Makerere University Business School, Uganda: Chapter Twenty four of Africa Casebook - Synergies in African Business and Management Practices: ISBN 978-9966-1570-0-3: AJBUMA Publishing, University of Nairobi - School of Business: VOL. I, 2012.Pgs 372-382.

[4]. CIA World Fact book(2012), "South Africa Geography", Web page: http://www.theodora.com/ wfbcurrent/south_africa/south_africa_geography.html.

[5]. Department of Agriculture-South Africa (2003): Maize production; Compiled by Directorate Agricultural Information Services; Department of Agriculture in cooperation with ARC-Grain Crops Institute.Printed and published by the Department of Agriculture, Pretoria, South Africa.

[6]. Dunn J. W., BerryJ. W., KimeL., HarshR. M., and HarperJ. K (2006): "Developing a Roadside Farm Market: Agricultural Alternatives". (C) The Pennsylvania State University 2006; Code \# UA434; 5M3/06mpc3995g: web-page: http://extension.psu.edu/business/ag-alternatives/marketing/developing-a-roadside-farm-markets.

[7]. Eastern Cape Department of Agriculture (2008): "Crop and livestock enterprise budgets", (un-published)

[8]. FAO-UN (2000): "Socio-economic impact of smallholder irrigation development in Zimbabwe; Case studies of ten irrigation schemes", SAFR/AGLW/DOC/002: Food and Agriculture Organization of the United Nations (FAO); Sub-Regional Office for East and Southern Africa (SAFR); Harare.

[9]. Kibirige D., Kiiza B., and ElepuG (2010):Analysis of Technical and Allocative Efficiency of Agricultural Productivity Enhancement Program on Maize Farmers;Masindi District (U), monogram Book; ISBN: 978-3-8383-7163-4, Published by LAPLambert Academic Publishers and printed in the USA and UK.

[10]. Kibirige D. (2013): "The Impact of Human Dimensions on Smallholder Farming in the Eastern Cape Province of South Africa" PhD Thesis: Department of Agricultural Economics and Extension, Faculty of Science and agriculture, University of Fort HareAlice South Africa.

[11]. Kodua-Agyekum C.(2009): "The transfer of technology to the rural poor: The case of Qamata Irrigation Scheme in the Eastern Cape Province of South Africa". Phd Thesis, Faculty of Humanities, Development and Social Sciences, University of KwazuluNatal, South Africa.

[12]. KohlsR. L. and UhlJ. N. (2002): Marketing of Agricultural Products (9th edition)

[13]. KwaZulu-Natal Department of Agriculture and Environmental Affairs (2006): "COMBUD Enterprise Budget".

[14]. Ostrom E.(1998): "Social capital: a fad or a fundamental concept?", Center for the Study of Institutions, Population and 
Environmental Change Workshop in Political Theory and Policy Analysis, Indiana University.

[15]. Padilla-Fernandez M. D. and NuthallP. (2001):Farmers' goals and efficiency in the production of sugar cane: The Philippine case, Farm and Horticultural Management Group Lincoln University, ISSN 1174-8796, Research Report 07/2001.

[16]. Statistic South Africa (2012): Census 2011, Statistical release P0301.4

[17]. The Encyclopaedia of Earth (2008)"Water Profile of South Africa", (Updated in May 2012), website: http://www.eoearth.org/article/Water profile of South Africa

[18]. Theyse M. (2014): "Trends in South Africa vegetable imports"; Fresh Produce Importers Association. 